\title{
Psikoedukasi dan Hipnoterapi untuk Penanganan Insecure pada Remaja
}

\author{
Zahro Varisna Rohmadani ${ }^{*}$, Tri Winarsih ${ }^{2}$ \\ ${ }^{1}$ Fakultas Ekonomi, Ilmu Sosial dan Humaniora, Universitas 'Aisyiyah Yogyakarta \\ ${ }^{2}$ Fakultas Ekonomi, Ilmu Sosial dan Humaniora, Universitas ‘Aisyiyah Yogyakarta \\ *Email: zahrovarisna@unisayogya.ac.id
}

\begin{abstract}
ABSTRAK
Pembelajaran secara daring (online) yang dilakukan selama masa berlangsungnya pandemi Covid19 membuat siswa mengubah metode dan pola belajar yang biasa mereka lakukan. Intensitas penggunaan smartphone dan jaringan internet sebagai sarana pembelajaran justru ikut meningkatkan aktifitas siswa dalam berinteraksi melalui media sosial. Para siswa SMA yang masih berada dalam kategori remaja ini jika tidak diawasi dalam penggunaan media sosialnya maka akan rentan mengalami perasaan insecure. Insecure adalah perasaan lemah, tidak percaya diri dan putus asa yang dialami seseorang akibat seringnya membandingkan diri sendiri melalui media sosial yang dimilikinya dengan orang lain yang dianggap lebih mampu atau berdaya. Perasaan insecure pada siswa ini harus segera diatasi karena siswa yang mengalami insecure memperlihatkan produktifitas belajar yang cenderung menurun. Solusi yang bisa ditawarkan adalah melalui psikoedukasi dan hipnoterapi yang diberikan kepada siswa untuk meningkatkan pemahaman diri dan penanaman sugesti yang positif.
\end{abstract}

Kata Kunci: hipnoterapi; insecure; psikoedukasi; remaja

\section{Psychoeducation and Hypnotherapy for The Treatment of Adolescent Insecurity}

\begin{abstract}
Online learning conducted during the Covid-19 pandemic made students change their usual learning methods and patterns. The intensity of the use of smartphones and internet networks as a means of learning actually increases student activities in interacting through social media. High school students who are still in this category of teenagers if not supervised in their social media use will be vulnerable to feeling insecure. Insecure is the feeling of weakness, lack of confidence and hopelessness experienced by someone as a result of often comparing themselves through social media that they have with others who are considered more capable or empowered. Feelings of insecurity in these students must be overcome immediately because students who experience insecurity show learning productivity that tends to decrease. The solution that can be offered is through psychoeducation and hypnotherapy provided to students to improve self-understanding and positive suggestion cultivation.
\end{abstract}

Keyword: adolescent; hipnoterapi; insecure; psikoedukasi

\section{PENDAHULUAN}

Terjadinya pandemi Corona

Virus Desease (Covid-19) bermula dari laporan tentang adanya kasus pneumonia yang penyebabnya tidak diketahui karena cenderung dianggap sebagai penyakit baru pada Desember 2019 (Baskara, 2020).
Penyebaran virus ini terjadi dengan cepat ke banyak negara termasuk di Indonesia, dimana kasus pasien covid-19 di Indonesia pertama kali di ketahui pada awal maret 2020 (Farisa, 2020). Berdasarkan laporan Satgas Penanganan Covid-19 (2020) pada 29 September 2020, tercatat 
jumlah pasien positif covid-19 telah mencapai 278.722 orang dengan sebanyak $74,2 \%$ diantaranya telah dinyatakan sembuh dan jumlahnya ini masih akan terus bertambah. Dengan terus bertambahnya korban pandemi Covid-19 ini, masyarakat dituntut untuk dapat menyesuaikan diri serta mengikuti setiap protokol kesehatan seperti mengenakan masker, membiasakan cuci tangan, dan menjaga jarak fisik (Physical Distance) (Sumartiningtyas, 2020).

Penerapan physical distancing ini dianggap mampu menurunkan kemungkinan penularan covid-19, namun di sisi lain himbauan untuk tetap berada di rumah saja menjadikan orang-orang merasa stres dan bosan saat hanya berdiam di rumah. Begitu juga dengan stres karena pembelajaran yang juga berlangsung secara online. Rata-rata siswa mengalami stres pada tingkatan sedang selama pembelajaran jarak jauh berlangsung (Harahap dkk, 2020). Oktawirawan (2020) menjelaskan ada beberapa upaya yang dilakukan siswa untuk mengatasi kecemasan tersebut antara lain dengan belajar mandiri, langsung mengerjakan tugas, berdiskusi dengan guru dan teman, berdoa, saling menyemangati, melakukan kegiatan hiburan lain (seperti menonton film, membuka media sosial, mendengarkan musik, bermain game), tidur, makan, dan berolahraga.

Hal lainnya yang juga dirasakan oleh siswa adalah perasaan bosan disebabkan aktivitas yang banyak dilakukan hanya dari rumah saja sehingga menjadikan mereka sering menggunakan media handphone untuk mengakses media sosial. Mengakses media sosial ini dapat menjadi hal positif, misalnya dengan mengakses chanel-chanel pemberi motivasi, menambah pengetahuan, menggali potensi diri, serta mencari inspirasi. Tetapi sebaliknya, jika siswa yang masih tergolong remaja ini salah dalam memanfaatkan chanel media sosial yang diikutinya, mereka justru dapat terjebak dalam perasaan tidak aman, tertekan, merasa tidak puas dan tidak yakin akan kapasitas dirinya sendiri. Hal ini terjadi karena remaja sering membandingbandingkan dirinya dengan orang lain di media sosial yang terlihat lebih baik dan sukses dibandingkan dirinya sendiri. Padahal setiap orang pasti memiliki kelebihan maupun kekurangan yang berbeda-beda serta tidak sama antara satu dengan yang lainnya.

Remaja merupakan tahap transisi dari anak menuju dewasa, yang merupakan salah satu tahap perkembangan manusia. Dimana pada masa remaja ini, mereka mengalami berbagai perubahan serta masih mencari jati diri. Siswa SMA/MA juga masuk dalam kategori remaja tengah, yang mana merupakan individu yang cenderung suka berkumpul dengan teman sebayanya, serta mudah terpengaruh dan memiliki keinginan serupa jika melihat orang yang seumurannya mempunyai sesuatu yang belum ia punyai. Misalnya, jika temannya 
sudah bisa memiliki penghasilan yang banyak atau memperoleh penghargaan tertentu yang belum ia dapatkan, para remaja cenderung akan merasa insecure. Demikian pula yang terjadi pada beberapa remaja yang bersekolah di salah satu SMA Muhammadiyah 2 Yogyakarta yang terlihat berdasarkan tanya jawab pada acara penanganan stres pembelajaran jarak jauh oleh penulis (Hasil tanya jawab pada Pengabdian Masyarakat di SMA Muhammadiyah 2 Yogyakarta tanggal 20 Agustus 2020).

SMA Muhammadiyah 2 Yogyakarta sebagai salah satu sekolah Muhammadiyah di Yogyakarta yang siswa-siswinya berprestasi juga ikut terkena dampak dari karena adanya pembatasan sosial ini, karena siswa/i nya belajar dari rumah. SMA ini berada di tengah kota Yogyakarta yang telah berdiri sejak 2 Oktober 1950 yang siswasiswi nya berprestasi dan membanggakan negeri ini. Diantara dari prestasi-prestasi yang diraih oleh siswa-siswi SMA Muhammadiyah 2 Yogyakarta diantaranya yaitu pada tahun 2019 menjuarai lima besar lomba Matematika nasional tingkat SMA/MA/SMK se-Indonesia yang berlangsung di Universitas Muhammadiyah Purwokerto. Pada tahun ajaran 2019/2020, siswa SMA Muhammadiyah 2 Yogyakarta tercatat sebanyak 33 siswa yang lolos SNMPTN. Ini juga merupakan prestasi yang membanggakan karena tahun sebelumnya yang lolos hanya 22 pelajar.
Selain prestasi akademik, terdapat pula prestasi non-akademik yang ditorehkan oleh siswa/i SMA Muhammadiyah 2 Yogyakarta diantaranya juara 3 kategori vokal putra dalam lomba Festival Lomba Seni Siswa Nasional (O2SN) tingkat Kota Yogyakarta, juara pertama lompat jauh, juara 3 badminton dan juara 3 pencak silat putra. Kejuaraan dari siswa/i SMA Muhammadiyah 2 Yogyakarta, dimulai dari adanya pendampingan dari guru-guru serta kepala sekolah yang sangat menginginkan agar siswa/i berprestasi dan mengharumkan negeri ini, terlebih warga Muhammadiyah pada khususnya. Sekolah mewadahi para siswa yang berbakat di bidang masing-masing, yang mana sekolah membuat program pembinaan ekstrakurikuler serta pembinaan akademik yang dikelola secara berkelanjutan.

Adanya segudang prestasi dari civitas akademika SMA Muhammadiyah 2 Yogyakarta, nyatanya masih terdapat beberapa siswa yang mengalami masalah kurangnya percaya diri, siswa yang kurang nyaman dengan dirinya sendiri karena merasa tidak mampu, merasa tidak berdaya, merasa tidak puas dengan dirinya sendiri, serta tidak yakin dengan kapasitas diri.

Hal ini perlu diatasi dengan menggunakan psikoedukasi serta hipnoterapi yang telah terbukti dapat menurunkan tingkat stres, cemas dan depresi pada individu yang diintervensi menggunakan metode tersebut. Sebagaimana yang kita 
ketahui sesuai teori bahwa insecure adalah perasaan yang mengarah ke stres, cemas dan depresi dengan gejala-gejala sering tidak percaya diri, menganggap rendah dirinya sendiri, merasa tidak aman dan tidak mampu, dan meremehkan diri. Terlihat dari hasil penelitian Kingsburry (2011) bahwa gangguan stres pasca trauma dapat diturunkan dengan hipnosis / hipnoterapi serta bahwa depresi, cemas dan stres dapat menurun setelah diberikan hipnoterapi (Setyadi dkk, 2016). Kumar \& Jena (2013) juga membuktikan bahwa hipnoterapi klinis mampu membantu pasien yang mengalami kecemasan. Demikian juga dengan Rohmadani (2017) yang membuktikan bahwa future pacing hypnotherapy dapat menurunkan kecemasan pada mahasiswa baru.
Selain hipnoterapi, juga diberikan psikoedukasi agar para guru dan siswa mengetahui kondisi yang mereka alami sehingga lebih aware dan mudah diberikan sugesti positif.

\section{METODE}

Sebelum pelaksanaan program penanganan yang akan dilakukan, penulis terlebih dahulu meminta izin dari pihak SMA Muhammadiyah 2 Yogyakarta untuk menandatangani surat kesediaan kerja sama untuk diberikan penanganan. Setelah proposal dinyatakan lolos, penulis menghubungi pihak mitra (SMA Muhammadiyah 2 Yogyakarta) kembali untuk menyesuaikan waktu / jadwal sehingga bisa selaras dengan waktu yang kosong untuk siswa SMA Muhammadiyah 2 Yogyakarta.

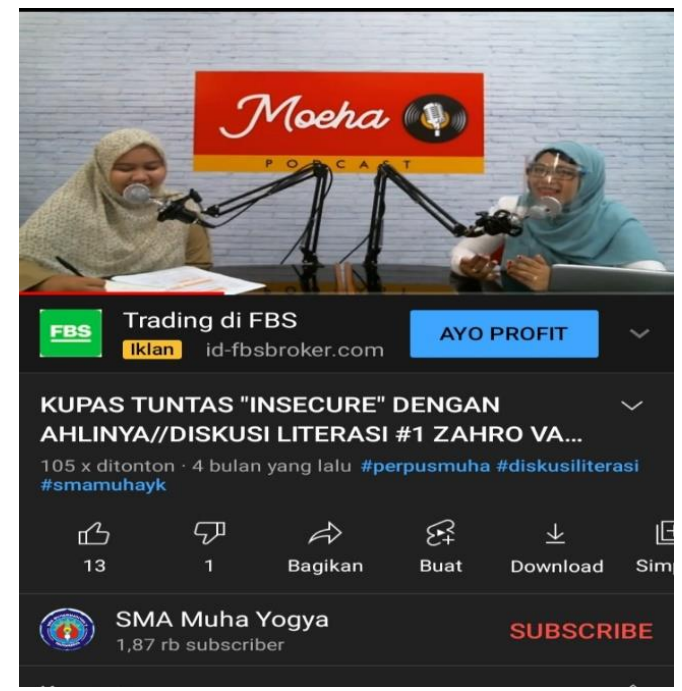

Gambar 1: Podcast Psikoedukasi Mengenai Insecure

Selanjutnya, kepala sekolah akan memberikan tanggung jawab untuk memberikan pendampingan pada siswa, dan memberikan sosialisasi terkait dengan akan dilakukannya program penanganan insecure ini. Siswa SMA Muhammadiyah 2 Yogyakarta yang mengikuti penanganan ini sekitar 100 orang. Metode atau cara yang akan 


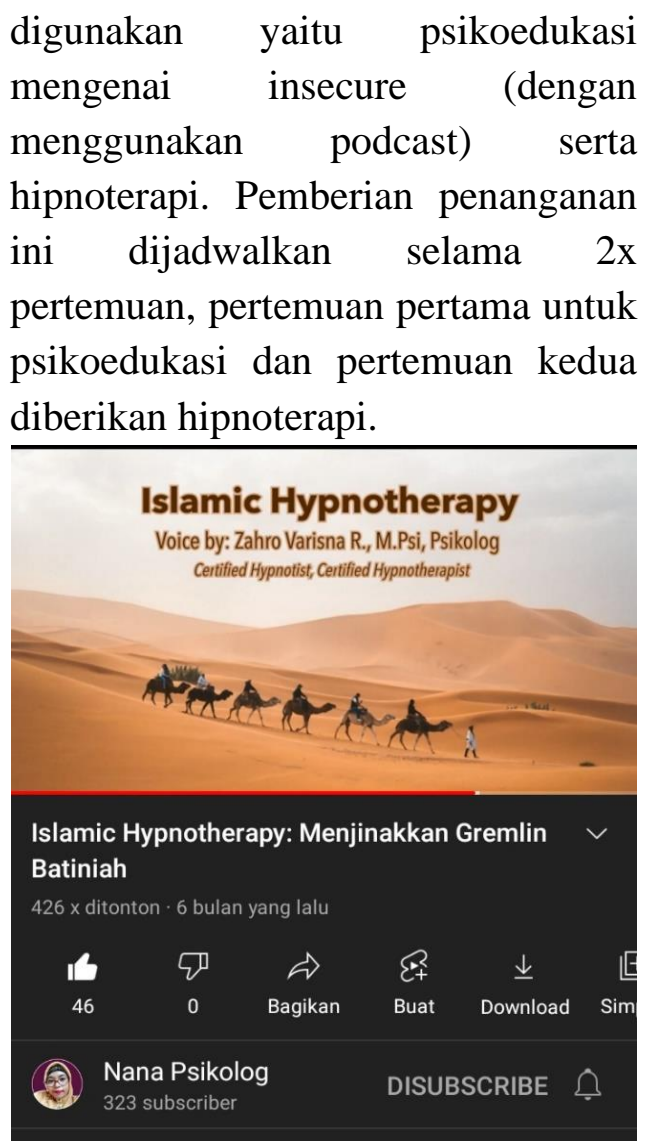

Gambar 2: Islamic Hypnotherapy untuk Menurunkan Insecure

\section{HASIL DAN PEMBAHASAN}

Setelah selesai diberikan penanganan berupa psikoedukasi mengenai insecure dan hipnoterapi, para siswa menjadi merasa lebih baik. Mereka yang awalnya mengeluhkan bahwa sering merasa tidak percaya diri karena sering mendapatkan bully dari temannya, sering diolok-olok karena kondisi fisiknya yang mungkin jerawatan atau gemuk.

Berdasarkan google form yang diisi oleh para siswa setelah selesai program dilaksanakan (setelah diberikan hipnoterapi), sebanyak $15 \%$ peserta mengatakan bahwa tidak ada perbedaan perasaan antara sebelum psikoedukasi berupa podcast dan juga hipnoterapi, namun sebanyak 85\% mengatakan bahwa mereka merasakan lebih tenang, merasa lebih berani dan percaya diri, merasa tidak insecure lagi, melihat manusia pasti memiliki kelebihan dan kelemahan, bermuhasabah terhadap diri sendiri serta membandingkan dengan diri masingmasing di masa lalu serta melihat pencapaian yang sudah individu dapatkan, merasa lebih baik karena berpikir masing-masing orang memiliki kelebihan dan harus lebih mencintai diri sendiri, serta lebih banyak bersyukur. Selain itu, peserta juga mengatakan bahwa menjadi diri orang lain belum tentu sebahagia yang kita lihat.

Hasil pengabdian masyarakat tersebut sesuai dengan yang dikemukakan oleh Cahyadi (2017) bahwa hipnoterapi bermanfaat untuk kehidupan manusia, serta dalam hal peningkatan kualitas diri dari seorang individu. Di dalam pengabdian masyarakat ini, memang insecure yang dialami oleh remaja dapat diatasi dengan menggunakan psikoedukasi agar peserta mengetahui apa itu insecure, apa yang harus dilakukan ketika sedang merasa insecure, serta hipnoterapi sehingga peserta menjadi lebih tenang dan siap menghadapi hariharinya, seperti yang dikemukakan pula oleh Kingsburry (2011) bahwa gangguan stress pasca trauma (yang mana dalam hal ini banyak ditemui pada siswa yang merasa insecure) ini dapat menurun setelah diberikan hypnosis / hipnoterapi. 


\section{SIMPULAN}

Mitra yaitu siswa/i SMA Muhammadiyah 2 Yogyakarta yang mengikuti program ini berupa psikoedukasi mengenai insecure dan

\section{DAFTAR PUSTAKA}

Baskara B. Rangkaian Peritiwa Pertama Covid-19. 18 April 2020. Retrieved from https://bebas.kompas.id/baca/r iset/2020/04/18/rangkaianperistiwa-pertama-covid-19/. 2020.

Cahyadi A. Metode Hipnoterapi dalam Merubah Perilaku. Syi'ar. 2017;17(2):73-82.

Farisa FC. UPDATE 12 Juli: Kasus Covid-19 Bertambah 1.681, Totalnya Jadi 75.699. kompas.com. 2020.

Harahap ACP, Harahap DP, Harahap SR. Analisis Tingkat Stres Akademik Pada Mahasiswa Selama Pembelajaran Jarak Jauh Dimasa Covid-19. Biblio Couns J Kaji Konseling dan Pendidik. 2020;3(1):10-4.

Kingsburry SJ. Hypnosis in the Treatment of Posttraumatic Stres Disorder: An Isomorphic Intervention. Am J Clin Hypn. 2011;31(2).

Kumar, A \& Jena SP. Effect of Clinical Hypnotherapy on Anxiety Symptoms. Delhi Psychiatry J. 2013.

Oktawirawan DH. Faktor Pemicu Kecemasan Siswa dalam Melakukan Pembelajaran hipnoterapi, dapat menurun insecurenya sehingga dapat dikatakan bahwa pengabdian masyarakat yang dilakukan ini berdampak positif terhadap mitra.

Daring di Masa Pandemi Covid-19. J Ilm Univ Batanghari Jambi. 2020 Jul;20(2).

Rohmadani ZV. Metode Future Pacing Hypnotherapy Untuk Menurunkan Tingkat Kecemasan Pada Mahasiswa Baru. J Heal Stud. 2017;1(2):125-9.

Satgas Penanganan COVID-19. Peta Sebaran. covid19.go.id. 2020.

Setyadi, A.W. Murti, B \& Demartoto A. The Effect of Hypnotherapy on Depression, Anxiety and Stress, in People Living with HIV / AIDS, in "Frienship Plus" Peer Supporting Group, in Kediri, East Java. J Heal Promot Behav. 2016;

Sumartiningtyas HKN. New Normal, WHO Tekankan Protokol Kesehatan dan Jarak Sosial Cegah Penularan Corona. kompas.com. 2020. 